DOI: 10.14526/2070-4798-2019-14-3-40-50

\title{
Traditional indigenous games in Costa Rica: an opportunity in the framework of the sustainable integration of Central America
}

\author{
Luis Bruzón Delgado* \\ Central American Educational and Cultural Coordination \\ Central American Integration System (CECC/SICA) \\ San José, Costa Rica (Central America) \\ ORCID: 0000-0002-1958-788X, sulayum@gmail.com*
}

\begin{abstract}
During the days of November 7 and 8, 2018, the first Festival of Indigenous Sporting Games was held in Costa Rica, with the participation of six ethnic groups of the eight that the country has. This fact supposes a qualitative jump in the promotion and recognition of a heritage in progressive dissolution by the penetration of globalizing cultural models. Materials. This article tries to justify, based on the interaction with the participants during the three days of the contest and the interviews held with them, the need to address a deep investigation about the importance of recovering and putting value to this type of practices in Central America, given its potential characteristics for development through processes of cultural resignification, community participation, intercultural dialogue and social cohesion. Research methods. Literature review, study of video materials. Results. This fact is more relevant in contexts of indigenous culture, considering the emerging philosophy of Good Living and the accused spiritual component that underlies the traditional games and sports of these communities. Conclusion. Revitalization of traditional games is revealed as a licit exercise of the cultural rights of indigenous communities and as opportunities to achieve the goals included in declarations of international forums. It is necessary to promote research about the possibilities offered by UNESCO, especially in regions such as Central America, as a way for peace, social inclusion and regional integration, among other purposes, and even more taking into account the upcoming celebration of the Bicentennial of the Independence of Central America, which has been joined by the eight countries that make up the SICA region.
\end{abstract}

Keywords: Traditional sports games, indigenous villages, social cohesion, youth participation, development.

For citation: Luis Bruzón Delgado*. Traditional indigenous games in Costa Rica: an opportunity in the framework of the sustainable integration of Central America. Russian Journal of Physical Education and Sport. 2019; 14(3): 40-50. DOI: 10.14526/2070-4798-2019-14-3-40-50

\section{Traditional sports games, cultural heritage}

Traditional sports games (TSG) are social manifestations based on an agreement of rules. Anyone who participates in a game accepts the rights and limitations established by those rules.

The game does not respond to a natural or biological behavior, as a social manifestation is the result of a transmitted learning (Mauss, 1934). As Parlebas (2001) points out, every game is an ethnomotricity, a mirror of the society that receives it, a microsociety or a society in miniature that shows social and cultural features of the context it represents. These are manifestations that behave like showcases in which values and distinctive features of their culture are reflected.

TSGs are of growing global interest. In August 2018, UNESCO, with the support of the World Confederation of Ethnosport (WEC), organized the Fourth World Consultation for the Safeguarding and Promotion of TSG, in Istanbul, Turkey. The
UNESCOAdvisory Committee in charge of advancing this process stated the importance of recognizing the contribution of TSGs to the strengthening of inclusive intercultural dialogue, and underlined the need to promote their safeguarding and transmission as a form of cultural heritage, through a set of guidelines.

The Central American countries were represented at this meeting by the Central American Educational and Cultural Coordination (CECC/SICA). Later, in November 2018, the regional Council of Ministers of Culture, held on San Pedro Island (Belize), committed to:

To support the Executive Secretariat of the CECC in its efforts before UNESCO to consider the incorporation of the SICA countries into the "group of friends of TSG (Traditional Games and Sports)", so that they may officially participate in the process for the recognition of this type of cultural heritage in the United Nations agenda, given that this is a priority area for promoting fraternity among 
peoples and the achievement of the Sustainable Development Goals (SDS).

Thus, Central America as a region decided to join a process of institutional and social dialogue, for which recognition at the local level will be necessary, since it is in each territorial reality where the TSG practice takes place. It is a strength and an opportunity to conform to the achievements of the SDG, to the territorialization (localization) of public policies and to the governing role of local governments. The territory cannot be understood without population and its activities without a territorial government (García González, 2018). The participation of national and local authorities in the Talamanca games is an advance towards this purpose.

Let us situate ourselves in the cultural framework. The TSG do not refer to culture in the statements of any of its 17 objectives. However, there is an increasing call in international forums and strategic documents to consider culture as a way to achieve global development goals. In Central America, the Central American Cultural Integration Policy (CCIP-CECC/SICA, 2016) seeks to recognize cultural expressions of Central American peoples as a determining factor in the territorial development. In other words, it supports the institutional declarations of the countries, which have gradually recognized their nations as multicultural.

Thus, the CCIP, which is based on the postulates of UNESCO's international declarations (2003 and 2005), refers to diversity as a step beyond the concept of identity; it also refers to the "senses of belonging" in the plural, beyond a single sense of belonging as an articulating factor of territory; and other notions, such as "diffusion of culture", "respect" or shared vision of culture", are replaced by "production of cultural knowledge", "management of regional interculturality" or "co-responsible management of culture" (CECC/SICA, 2016, p.1). 10-11).

In other words, culture, in which traditional games and sports are framed, is alive and it is a source of research and knowledge. In this sense, as intangible cultural heritage, it is related to social cohesion and the development of communities. The Ibero-American Cultural Charter (OEI, 2006) underlines that cultural heritage represents a long experience of original and unrepeatable ways of being in the world. In this context, traditional games are also part of the living culture of communities, reflecting their concerns and desires, their knowledge and projections towards ways of life in community (UNESCO, 2003).

Cultural heritage and its direct relationship with the strengthening of cultural identities, projects the processes of dignification and development of traditionally excluded vulnerable groups. Their identity or identities, strengthened from within, will contribute to a better life, to "the good living", according to the indigenous conception.

TSG, an opportunity for inclusion and social cohesion

Social cohesion is one of the key elements to which the first indigenous sports games festival in Costa Rica can contribute, in a context in which the country's indigenous population - which accounts for approximately 2 per cent of the total - has traditionally been invisible, not to say forgotten by the majority of the population, more than 65 per cent of whom live in the Central Valley. In this sense, the realization of traditional games, as part of a cultural manifestation, supposes a progress towards the strengthening of the relations of complementarity, sense of belonging, solidarity, trust and collaboration between the members of the communities.

The traditional game invites to the social encounter of people who participate in a game and express the will to share an experience with other protagonists. Traditional games represent the search for the pleasure of sharing an experience of relational and emotional well-being with other people.

Good living is born in the indigenous Andean cosmovision around the concept of Sumak Kawsay (good life, in Ecuador) or Suma Qamaña (good living, in Bolivia). Vindicated by the ancestral indigenous cultures of these countries and incorporated respectively into their constitutions in 2008 and 2009 (Martínez \& Larrea, 2010; Gudynas \& Acosta, 2011; Barranquero, 2012), this theory seeks to move away from the colonial program of development in order to emphasize the disquisitions derived from reflections about indigenous knowledge, environmental crisis and dependency theory.

The social cohesion to which the games contribute is built on "cultural autonomy" (Romero, 2005), which makes it possible to define the destiny of peoples according to their own vision. Recovering traditions is a respectable decision from an equality perspective. It implies placing the production of culture at the centre of community life, in order to generate conditions of appropriation, consolidation and equity, from a dialogical, horizontal, egalitarian perspective, respectful of multicultural visions that maintain a common denominator of identity.

In this sense, the exchange of social relations established by traditional games transmits to the participants a feeling of belonging to the group, of collective identity, because through these collective adventures and challenges each person affirms and is perceived by the other players as accomplices of a boiling of emotions (fundamentally positive) that this exchange generates (Parlebas, 2001).

In the concept of good living there are other 
values, such as ancestral knowledge, social and cultural recognition, environmental balance, codes of conduct, ethics, spirituality, human values and the vision of the future of indigenous communities. In short, a reconceptualization of development from the cosmovision of the original peoples that in one way or another collect the traditional games.

Promoting social cohesion and recognizing interculturality (that is, the dialogical and participatory sense of multiculturality) is an opportunity for developing and achieving consensus, in a framework of democratic openness to cultural pluralism, diversity of beliefs and worldviews, tolerance and maintenance of peaceful societies, which is very necessary in Central America. This will require the assumption of the equal dignity of cultures through the conception of cultural relativism, a sine qua non for peaceful coexistence among peoples and social inclusion.

\section{Intercultural dialogue through TSGs}

With the idea of overcoming global concepts of identity towards interculturality, UNESCO (2010, p. 10) alludes to the need to create a virtuous circle between cultural diversity and intercultural dialogue in a context of rapid social transformation in order to achieve conviviality. It reminds us that xenophobia still exists and is far from being eradicated, whether at home, the neighborhood, the nation or worldwide.

This intercultural dialogue requires opportunities for the participation of minorities in that dialogue. Minorities traditionally marginalized or excluded from state public policies, which have not been sufficiently inclusive and, consequently, have not had adequate spaces of expression to speak and give voice to multiculturalism. Nor has there been such conviviality in social terms, leading to almost permanent isolation and oblivion of indigenous or Afro-descendant populations, largely ignoring their cultural manifestations or viewing them simply as examples of folklore from an ethnocentric viewpoint.

UNESCO (2001) also refers to the fruitful diversity of the world's cultures as a common asset of humanity for the benefit of present and future generations. Cultural diversity refers to the multiplicity of ways in which the cultures of groups and societies are expressed, inwardly and outwardly. Cultural diversity is also manifested through the various modes of artistic creation, production, dissemination, distribution and enjoyment of cultural expressions, whatever the means and technologies used (UNESCO, 2005).

Within this framework, traditional games and sports function as agents that contribute to cultural development as the backbone of collaborative processes based on dialogue, manifested through motor and expressive languages (Lavega et al., 2006). When playing, bodies act as cultural signs that revive culture through motor actions with rules. The unity that characterizes TSGs is precisely the diversity and originality of their rules. In each society the games have different ways of promoting the interpersonal relationship among the participants, a feature that illustrates the global unity of human culture.

Consequently, traditional indigenous sports games represent the full exercise of the cultural rights of the participating communities. Their celebration generates the source of meaning and energy for aspects such as peace or environmental sustainability. From this perspective, there is a commitment to the cultural appropriation of traditional games, with confidence and pride, and without their expression being embarrassing, something that unfortunately often happens in younger generations.

Today, many communities prefer not to recognize a sense of belonging to a specific territory or cultural group because they feel excluded. This attitude, which denies the fulfilment of the cultural rights of the individual as part of human rights, moves the focus away from that democratic dialogue. In the case of ethnic minorities, their duties and rights are marked both by the legal system and by ancestral guarantees and the role they play as guardians of their own cultural codes (Lora, 2015). In the development of the traditional indigenous games of Talamanca, Alejandro Swaby (personal communication, December 7, 2018) indicates that the past and the present unite the struggle of indigenous peoples for their survival and the struggle for their cultural rights.

Central American cultural diversity, a field for action

Central America is diverse from a cultural perspective and a youth capable of mobilizing social change emerges from it. A youth that demands opportunities for development based on new learning. Young people, especially in rural areas, are eager for knowledge. Above all, they are eager to listen and speak in order to build new options for their future (Bruzón, 2016).

From the cultural perspective on which this reflection is based, we can establish a common thread based on the geographical division on which the notion of Central America is usually built. We will combine historical, political, cultural and social aspects to delimit the region territorially. In this way, we will refer in this article to the isthmian countries that currently make up the Central American Integration System (SICA): Belize, Guatemala, El Salvador, Honduras, Nicaragua, Costa Rica and Panama.

They have merged influences of the Mesoamerican cultures -in which the inheritance of the great Mayan civilization in countries like Belize, Guatemala, El Salvador and Honduras stands out-, 
with others coming from the south, such as those of Chibcha influence in communities of Costa Rica and Panama.

Central America was a meeting point between migratory currents from the north and the south, fulfilling its role as a bridge between the two great continental masses (Fonseca, 1996). The strength of the region's Afro-descendant cultures, with their own multiculturalism, should not be overlooked, nor should the influence of the multiple cultures that have been incorporated into the rich sifting of today's Central American cultural diversity, which transcends the initial European presence that began with the Spanish conquest.

Pérez (2012) recalled that, in El Salvador, a detailed ethnographic survey conducted in 2001 had found a total of 67 communities, distributed throughout the country, where the persistence of indigenous cultural traits and practices was observed. The study also served to identify three different ethnic groups: the Náhuat/pipiles, the lencas of the potón branch and the cacaoperas or kakawiras. Neither Lenca nor Cacaopera survive linguistically; Nawat is still spoken by some elders and only in families, although there are cultural revitalization projects, as will be seen below.

In the west of Honduras and Nicaragua the Mesoamerican cultures are prolonged; in the east, the indigenous peoples of the Southeast Central America, who keep close linguistic and cultural kinship with the indigenous civilizations of the North of South America. To these two cultural traditions are added other, more recent traditions from the Caribbean: Garífunas and Afro-Caribbean (Pérez, 2012). Honduras also has the indigenous Tolupanes or Xicaques, the Pech, the inhabitants of the Honduran mosquitia, the Tawahka and the Miskitos. In Nicaragua, apart from the Miskitos, we can find indigenous groups such as sumu mayangnas, ulwas and ramas, and the aforementioned Afrodescendants, Garífunas and Creoles.

These groups struggle to conserve their traditions and languages, many of them in danger of extinction. The ethnic variety continues through Costa Rica and Panama. In Costa Rica, there are still some reminiscences of the Chorotega culture in the northwest of the country. The maleku fight to avoid the extermination of their identity, which has happened practically with the huetar culture. Other indigenous groups in the country are the aforementioned ngöbe, brunca, teribe, cabécar and bribri, these last two live -as we have said- in the Talamanca region, in the southeast of the country. On the Caribbean coast, we can also find the population of Afro-descendant origin, which, like in Panama, comes from the workforce mobilized from Barbados and Jamaica (Pérez, 2012) -in the Panamanian case for canal construction- .

Pérez (2012) completes the map of Central
American cultural diversity in Panama, quoting groups from the Kuna-Yala Shire (San Blas), the Madungandi Kuna Shire, the Emberá-Wounaan Shire, the Ngöbe-Buglé and the Wargandi Shire, as well as making reference to the struggles (in 2002) of the Naso Teribe people for the establishment of a region of their own in the area of the Sixaola River, on the Costa Rican border

\section{TSG, cosmovision and spirituality}

The game does not appear as pure frivolity, it is part of a cultural identity in each community linked to local ways of life, beliefs and passions (Lavega, Lagardera, Molina, Planas, Costes, \& de Ocariz, 2006). During Talamanca's traditional sports games, indigenous leader Alejandro Swaby (personal communication, December 7, 2018) said that those who lose their identity and self-esteem end up despising themselves. The contest is part of the promotion and development of traditional indigenous sports, as part of a strategy from which other aspects are derived, related to the ultimate goal of relational well-being or development. In short, it has always been an aim of indigenous peoples to achieve a harmonious life, in relation to the elements that make up their cosmovision, something that historically has not been easy for them. As the Conceptual Note of the festival rightly points out, ...in the ancestral epoch, where every minute of daylight began the activities that consisted of fighting with the forces of the rivers, conquering hills, reaching products and by-products of the forest, tilling the land. There was no equipment, machinery, the only driving force was that of men and women (...) survival strategies required agility, concentration and intelligence.

The TSG find in the spiritual world a basis for their existence, conservation and development. This knowledge based on an oral tradition has been their main way of transmission and consolidation. Through orality, community existence, work, relationships, education, etc. are developed. And the figure of the narrator who transmits collective wisdom is fundamental, as a function that has usually been assigned to the elders of each culture (Sánchez Paredes, 2018).

What is certain is that the Talamanca territory is today the largest area with indigenous presence in Costa Rica. And in spite of inevitable processes of acculturation, which have contributed to the gradual disappearance of manifestations of their own cultural identity, they still preserve to a large extent the knowledge of their traditional knowledge and the oral histories that sustain their conception of the world, thanks to actions of endoculturation that have been maintained over time.

Harris (2001, p. 21) defines endoculturation as "a partially conscious and partially unconscious learning experience through which the older 
generation incites, induces and forces the younger generation to adopt traditional ways of thinking and behaving". In Talamanca, the preservation of the original languages, which are still spoken, has undoubtedly contributed to this. Even today, their reading and writing (the Latin spelling was endowed later) is taught in indigenous schools under the auspices of Ministry of Public Education.

The Bribri and Cabécar languages enable the original meaning of the conceptual structures of the Talamancan cosmovision to be maintained. The oral tradition has been key as a chain of transmission of intergenerational knowledge, it has been its own "university", as some community leaders express in conversations held with them. In Talamanca, it is usual to refer -and this has also happened in the celebration of sports games- to the respect professed to the elders as great repositories of the local culture. The elders (women are also included) are venerated as authorities of indigenous knowledge, in keeping with the great power that the gift of the word, its persuasion or conviction implies, which is a skill necessary to consider not only the meanings of the word itself, but also gestures, modulations and tone of voice (Sánchez Paredes, 2018).

Their stories have been preserved, through narrations, in which the transcription into Spanish would take us, if we were to make a sketch, from the creation of the world by Sibú (God), to the great house of human beings, the úsure, represented today in the traditional conical house, with the same natural materials that are used in some of the sports games. The conical house is not only the traditional house (not used since the arrival of the United Fruit Company in the 1930s), it is the indigenous world itself, with its different ranges of spirituality around the concentric rings that woods and vines make up to support its structure.

The traditional sports games are thus integrated into a stage of great spirituality. And so it happens with the map of indigenous cultures that have been able to maintain their identity and the production of knowledge on the basis of an orality that accepts the constant changes of the universe, but respects its essence and values in each topic of the environment and its conservation (Sánchez Paredes, 2018).

In spite of the distances, when participating in the great collective meeting of the traditional games contest in Talamanca, some parallels can be found with the elaboration of traditional housing. Both celebrations can be considered a "cultural construction", considering the use of natural elements, spirituality, festivity, ceremonial food and drink and respect for the elderly. All this is present, with the addition of the intercultural mix, as other worldviews are incorporated. It maintains the concept of ritual, celebration, the sense of sharing the chicha and other aspects. There is no doubt that the spiritual dimension is present, although many meanings have been lost due to intergenerational ruptures in the processes of endoculturation, something very frequent in the Central American region (Bruzón, 2016).

Returning to the subject of hunting, the elements used for it (bow and arrow, spear, blowpipe... used now in sports games) are the object of the same sacralization. A group of young Talamanqueños from the community of Tayní, in Alto Coén, used their own blowpipe in the competition, which was probably used by the Sukias or Awapa (indigenous doctors) in their rituals. The blowpipe is also mentioned in the Popol Vuh, acquiring a cosmogonic sense that transcends its functionality as a weapon:

They were accompanying their older brothers when they left and began to shoot with their blowpipes. The number of birds making noise on trees was countless (Colop, 2011, p. 64).

\section{(...)}

Then they passed over a river of rotting water and over a river of blood, places where they would be defeated, thought the Xibalba; But they did not touch them with their feet, but on their blowpipes they passed them. (p. 81)

\section{Celebration of the I Festival of Indigenous Sports Games in Talamanca}

In view of these initial considerations, this study had as an objective the identification of sociocultural findings of the First Festival of Indigenous Sports Games of Costa Rica, held in the village of Progreso, in the Cabecar indigenous territory of the municipality of Talamanca, located about 250 kilometers from the capital, San José. The contest was organized by the Asociación de Desarrollo del Territorio Indígena Cabécar (ADITICA), with the support of the Instituto Costarricense del Deporte y la Recreación (ICODER), the Ministerio del Deporte y la Recreación (MIDEPOR) and the Universidad Estatal a Distancia (UNED). Its inauguration was attended by the President of the Republic of Costa Rica, Carlos Alvarado and the Minister of Sport, Hernán Solano.

A total of 52 athletes participated in the festival, 18 of them women. Most of them are between 18 and 35 years old. The events took place over the course of a day, with order and discipline. The greatest experts in bow and arrow, blowpipe, etc., were part of the jury. In addition, due to the initial level of some participants, they induced the young people in the use of these elements to generate a quick learning that would allow the competition. ADITICA's facilities were improvised accommodation for most of the delegations, which in some cases were accompanied by leaders and family members of the athletes.

Methodology, instruments and procedure of the investigation 
It is necessary to clarify that this research is, above all, an invitation to open a path to a broad research process on TSGs in Central America, with the necessary support to obtain, in the medium and long term, findings that would allow their consolidation and linkage to public policies for social integration.

In other words, the research presented here has a series of limitations that condition its scope, which, however, in no case should be overlooked. The research was approached from a qualitative perspective, understanding the most appropriate ethnographic method, "the structured path that the scientist follows to construct a sense of knowledge and knowledge and to produce theories about one or several phenomena observed or created in reality" (Rodríguez, 2011, p. 4).

Culture and communication are therefore brought together in a descriptive and data-gathering dynamic, in order to process developing aspects in the context of TSGs and indigenous communities. The researcher's aim is to approach the world "out there" and understand, describe and sometimes explain social phenomena "from within", analyzing experiences of individuals or groups, analyzing interactions and communications as they occur, in order to understand how people build the world around them (Angrosino, 2012).

From this perspective, it was important to use the video camera to document, as far as possible, not only the practice of the contest, but also to capture the context, emotions and statements of some participants, identified by their level of leadership in the community.

The researcher used the participant observation technique to provide an account of the reality studied and described, having in mind that, as Scribano (2008) points out, the role of the observer influences what is observed, and that, therefore, in the description and configuration of the final text there is a load of subjectivity mediated by interpretation in the analysis of discourse.

Due to the value that this article tries to confer to oral tradition, the speeches pronounced by the elders -men and women- in the proper inauguration of the event, after the institutional protocol, are especially significant. This took place during a solemn act in the "rancho" (traditional house) of ADITICA, at night, the sacred moment in which mythical stories are normally told.

In addition to the speeches, the voice, the word, the indigenous orality was also manifested in the interviews with some young indigenous participants in the festival of traditional games and sports, after the competition.

The researcher used the semi-structured interview strategy as a communicative strategy, in order to approach reality as it is observed by the different strategic actors of the process. Gradual interest was sought in meanings rather than facts, feelings rather than knowledge, interpretations rather than descriptions (Ruiz \& Ispizua, 1989, p. 129). It was a conversation oriented around a general script, with basic questions around:

- Development of the games

- Cosmogonic balance, good living and modernity

- Meanings for the community

- Emotions around coexistence

- Desires and concerns for the future

The informants were as follows:

- C.G., from the brunca community.

- N.P., from the Terraba community.

- R.S., from the ngöbe-buglé community.

- P.G., from the brunca community.

- G.M., from the cabécar community of Talamanca and coordinator of the organizing committee of the games.

As a procedure for content analysis, the researcher used the Discourse Analysis (DA) technique, in the sense of the different levels of interpretation of the symbolic contents that underlie the development of TSG practice. As Angrosino (2012) points out, human interaction is reflective, that is, people interpret keys (words, gestures, body language or the use of space and time) to maintain a common vision of reality. The $\mathrm{AD}$ methodology gives great symbolic value to the analysis of the meanings conferred by the interviewees. The work of the researcher focused on unraveling the significant value of language towards understanding the actions of the community and thus conferring new meanings to the practice of TSG in a context of tension between the past of the "elders" and views projected by youth.

Contribution of the first festival of indigenous sports games towards a better life (findings)

On the basis of the theoretical concepts previously raised, it can be inferred that the coexistence with the people who participated in the contest allowed to understand certain clues that compose nowadays the feeling of the indigenous communities in relation to the importance of recovering and promoting the traditional games and sports (TSG9. The conversation with the protagonists and some subsequent interviews allowed access to certain clues for their understanding within the cultural codes that are handled within the of the conceptions of the Good living and the inherited cosmovision through, fundamentally, the oral transmission, which, in turn, are relevant considerations in the context of the SDG.

The traditional games carried out in Talamanca allow the experience to be framed in the sense that Appadurai (2004) gives culture as an aspiration capacity for a better world, which in other words could be understood as development and which the indigenous communities prefer to call Good 
living. In short, to create conditions for a dignified life based on the drawing of a line that unites the past, the present and the future. The ability to aspire is not possible without cultural diversity, its manifestations, its sets of values, meanings and beliefs. All this leads to the ideas of dignity and hope in a better future for the people.

The following findings can be drawn from the speeches, interviews and conversations held with participants throughout the event:

1. TSGs contribute to the reaffirmation of identities and intercultural dialogue.

The coexistence established between the different cultural groups gathered in Talamanca demonstrates that there is a common denominator among these peoples in relation to the practices represented. "They were uses for subsistence and now become a discipline for rescue and revitalization" (C. G.). The games allow parallels to be drawn between the logical differences of each group, which enriches the cultural heritage. P.N. affirms that "the way of pointing with the bow and arrow is different in each case, but it allows to understand that the cosmovision is sustained on similar bases".

This reflection is reflected in the reiterated phrase pronounced by the speakers in speeches and conversations referring to "we, the indigenous...". In this regard, C.N. indicates: "We are part of a cultural heritage, a genetics that transcends millennia and yet, we are here, enjoying, trying that these practices do not die by calling them games and all those elements are in every speech". The organizer of the games, G. M., thinks that "the contest has unified the indigenous peoples, since 12 of the 24 indigenous territories of Costa Rica were represented". This leads him to dream about the great philosophy of Good Living, that is, to have a dignified sunrise and sunset.

Coexistence has given way to mutual knowledge, to a sense of intercultural respect. P. G. expresses himself in these terms: "We are from different peoples, but here we are as one. This is very important, because it is a union of indigenous peoples. I have shared, I have learned with people who know a lot about sports games. P.N., for his part, believes that coexistence generates learning and, at the same time, new questions, something he considers positive.

Non-indigenous people also can get closer to new worldviews and the way other cultures live. This helps to eradicate racism, xenophobia and mutual misunderstanding.

2. TSGs contribute to restoring intergenerational dialogue

This meeting point allowed direct contact between young and old. The elders were judges of the games, their involvement was total. The young people consulted them, asked them for advice (G. M.). "It is a return. Many older people believed that these games were going to disappear and with the contest the intergenerational dialogue was recovered" (P.N.). The elders showed their concern about the gradual disappearance of these practices, but at the same time they regained hope. Calling these practices "games" and turning them into a discipline helps to consolidate them as part of the cultural heritage, according to C. G., who adds that young people have found in the recreational and cultural a baseline to work and avoid losing the essence and the joint work with the elders, as a way to strengthen cultural roots.

G. M. emphasizes that it was a personal motivation, associated with the death of his grandfather, a great sage of the Talamancan culture, which encouraged him to organize the sports games: "It was a very hard moment. From there I focused on trying to recover cultural identity through these practices, to help define us as indigenous in its full dimension. This made me want to share my desire. It was when the Asociación Deportiva Indígena Cabécar de Talamanca (ADICATA) was born, he was president. This way I wanted to honor the memory of my grandfather, uniting sport and culture.

According to R.S., it is necessary to emphasize the internal dialogue of each culture. We are in a moment in which the young and the old take different sides and there is no way to take the same path. At that point, a conversation is established and that's what the games have accomplished. The young people have approached, through the explanations of the elders, a culture that they have really lived - without being conscious. According to him, young people alone are never going to approach the elders and ask them about the meanings of their culture. The fact that this approach is naturally given through games is of great value, the same value that he attaches to the fact that this competition, which has taken a lot of work, has been organized by young people.

3. TSGs encourage women's participation

TSGs allow all actors to speak a common language: the driving force. When women participate in this type of manifestation, they become visible through this body language, reviving the memory of the local culture in a clear, direct and profound way (Lavega, Etxebeste, Sáez de Ocáriz, Serna, \& During, 2016).

G.M. emphasizes the importance of the matrilineal condition of indigenous communities such as those of Talamanca, in which, when a child is born, automatically belongs to the mother's clan. He defines this as "a marvelous act of life". However, it also highlights the fact that the role of indigenous women in recent decades has changed, cultural behaviors have changed, and social ills such as "machismo" have been adopted. "That's why in the indigenous sports games we made the decision that women participate in all categories," she adds.

R.S. points out: "The question of women is a big question and at the same time very easy to answer. 
There are women who are much stronger than men. In these games, women are representing what the indigenous female gender really is. They have been able to show their real value, regardless of their age. Besides, P.N. points out: "The role that education can play is important, although in the past it was responsible for braking the intergenerational dialogue. Education now has the obligation to recover it, considering that now there are indigenous professionals working in their own communities.

Participating in the TSG is a fabulous showcase of bodily signs, of interpersonal relations of the local immaterial culture. Through body language, through motor actions, women learn to codify, decode and interpret those cultural signs (Parlebas, 2001) so important to perform the social function that their culture establishes.

4. TSGs instill a group nexus around emotion and joy.

Since our birth, popular culture in general and the traditional sports game in particular, have played a fundamental role in the "emotional literacy" of its people, acting as ecological mechanisms (Milton, 2005).

By playing, the person discovers the pleasure of living with others, the search to "live together", to communicate and to share common emotions. When we participate in a TSG, each person projects the emotions he or she lives in a two-way direction: towards himself or herself, bearing witness to the subjective process of that experience and, at the same time, constructing a fabric of emotions shared and complemented by the other participants, which favors learning ways to dialogue and get excited in the face of significant social events. The process of emotional socialization demands that we learn and assimilate the emotional reactions to the guidelines and norms established by our society. Various studies generated by TSG confirm that they are, above all, manifestations that trigger intense positive emotions (Lavega, Alonso, Etxebeste, Lagardera \& March, 2014).

Emotion produces a joy reiterated by the participants in their statements, giving it a meaning that transcends the purely playful. Joy unites the past and the present, connects the feelings of the elders with the living of the young people in an unpublished experience, which gives them the basis for harmony with their cultural codes and values. G. M. reiterates that games unite the past and the future by cultivating cultural identity: "These young people can continue to study and develop, but they should not be ashamed of their culture. Quite the opposite. Games are an opportunity to feel proud, not to forget their roots. Let joy not be lost in the hustle of daily life, because it is a joy that comes from the fact of existing" (G.M.).

C.G shares this same opinion, for him the games rescue a joy that had been lost due to the suffering of indigenous peoples throughout history: "In Boruca, the construction of the inter-American highway, under the premise of an alleged development, literally divided the community. The State exercised pressure against indigenous roots, as a consequence the language lost its strength. The games prevent from falling into the same situation. Let joy serve not to be ashamed of being different. In this way we build a truly multicultural State, respectful of diversity. This way, we don't deny our identity, since sometimes we doubt. P.N.: "We have been focused on resistance and we had forgotten the playfulness of this type of manifestation, the laughter, the fun it is to share. We've locked ourselves a lot.

5. TSGs reflect a spiritual sense.

They are based on the conception of belonging to the earth. "A landless Indian is a dead Indian," says Alejandro Swaby (Bruzón, 2003). The earth has all the elements that are used in games. They are part of the indigenous worldview. "You have to understand that these elements have life (G.M) and we are responsible for how we use them. We are responsible for their cultural use, for that cultural knowledge. Oral tradition is rescued. The elements that are used in the games are elements that imply a necessity for subsistence and subsistence always has something spiritual: "Killing an animal implied a ritual, we had to ask permission from the owners of nature" (C.G.).

P.N. contrasts the ancestral part -the past, the traditional, the spiritual- with the present world -the conception of modernity, the technological advances-, reaching the conclusion that today's indigenous youth live between two welldifferentiated worlds: "It is important to rescue the good from one and the other and turn it into a dialogue. What serves me on one side and the other and how I conserve the core of my tradition and the core of tradition, fundamentally in these last 500 years has been resistance. If we stop practicing, we lose".

6. TSGs allow the re-signification of ancestral practices.

Practicing traditional sports games opens up new interpretative possibilities in a world that does not escape globalization. P.N.: "The fact that a boy or a girl runs carrying a piece of firewood means that he or she can carry many other things in the community. What does it mean to be accurate with the bow and arrow? The word. The right word always. Games allow us to relive aspects of our culture that we had never imagined ourselves".

For P.N. to hold this contest is important, because these practices were part of everyday life in indigenous life. "Now it is recovered and we can allow ourselves a resemantization, a change of objective and turn it into a deep meaning. For example, if a boy or a girl lifts a heavy log and carries it, it also means that they can carry many things for 
their community. To be certain with a bow, refers me to words: the right word always. In other words, we can ask how these games can revive aspects of our culture and tradition that we ourselves have not imagined".

P.N. adds the importance of the link with the earth. Land is something that is always claimed by indigenous peoples and this also has to lead us to reflect and rethink this relationship: "How can I show the land that I love it? The materials we use are primary. If our environment, our tradition, our experience does not exist, we will not have materials to carry out these practices. There are no games, there are no places, there is no language, no history, there is nothing. We would be defeated, I insist. For me the main concern of all this is that, as indigenous people, we don't understand the importance of living together and living together within our land, understanding ourselves".

\section{Prospects for the future}

Regarding the future of the games, G.M. says: "It was the first edition. For me, it has been a success, because we have achieved the first step, which was for athletes not to deny their cultural identity, but there is much to improve, strengthen, rescue. I'm already thinking about the second edition.

P. G. adds: "This has to be taken to other territories, to other communities, so that everyone will see the importance of the country's indigenous peoples, while helping us to recover traditions that are no longer sought in many communities.

C.G. emphasizes the importance of the decentralization of culture, not always holding these events in the capital or in other important cities of the country: "It is better that the same institutions go to the territory, live with them, as the Minister of Sport did, always with the community, in their place. And P.N. adds: "We have to assume the commitment that this must continue, it must grow. For the next occasion, wherever it may be, there must be greater participation, with adolescents, children, girls. That is vital, it is a space to maintain and not let it collapse like other things that we have not known how to manage in time. We have to learn from those experiences and ensure that the games do not disappear, that they can compete and share. Why not turn this competition into a qualifying round for the World Games?

\section{CONCLUSIONS}

Despite being the first edition, despite logistical limitations and the low attendance of participants, the organizers and participants in the First Festival of Indigenous Sports Games of Costa Rica consider that its arrangement and development has been a success and are expecting the second edition. Physical activity, leisure and coexistence, have been expressed from a deep cultural root, in which intergenerational dialogue has allowed new models of relationship and the perspective of new narratives and meanings of a cultural heritage in the process of being forgotten.

Its revitalization is revealed as a licit exercise of the cultural rights of indigenous communities and as opportunities to achieve the goals included in declarations of international forums and the SDG. It is necessary to promote research about the possibilities offered by TSGs, especially in regions such as Central America, as a way for peace, social inclusion and regional integration, among other purposes, and even more taking into account the upcoming celebration of the Bicentennial of the Independence of Central America, which has been joined by the eight countries that make up the SICA region.

\section{REFERENCES}

1. Angrosino, M. Etnografía y observación participante en investigación cualitativa. Madrid, España: Ediciones Morata. 2012.

2. Appadurai, A. The Capacity to Aspire: Culture and the Terms of Recognition. En W. Rao, \& M. Walton (Eds), Culture and Public Action. 2004: 59-84.

3. Arévalo, J. M. La tradición, el patrimonio y la identidad. Revista de estudios extremeños. 2004; 60(3): 925-956. URL: http://sgpwe.izt.uam. $\mathrm{mx} /$ files/users/uami/mcheca/GEOPATRIMONIO/ LECTURA2E.pdf

4. Barranquero, A. De la comunicación para el desarrollo a la justicia ecosocial y el buen vivir. CIC Cuadernos de Información y Comunicación. 2012; 17: 63-78. UTL: http://revistas.ucm.es/index.php/ CIYC/article/view/39258/37841

5. Bertos, E. S. La oralidad maya, original de la traducción de Ximénez.In-Traduções Revista do Programa de Pós-Graduação em Estudos da Tradução da UFSC. 2014; 6: 171-182. URL: http://incubadora.periodicos.ufsc.br/index.php/ intraducoes/article/viewFile/2761/3293

6. Bruzón, L. El tigre de agua, apuntes de un viaje al alma indígena de Talamanca. Ediciones Perro Azul, Costa Rica. 2003.

7. Bruzón, L. Aplicaciones del audiovisual etnográfico a procesos de desarrollo e inclusión social en Centroamérica a partir del rescate y revitalización del patrimonio cultural. Doctor's thesis. Universidad de Huelva. 2016.

8. Canclini, N. Culturas híbridas: estrategias para entrar y salir de la modernidad. México: Grijalbo. 1989.

9. Cháves, A. G., \& Vásquez, F. G. La casa cósmica talamanqueña y sus simbolismos. Euned. 1989.

10. Colop, S. Popol Wuj. F\&G Editores. Biblioteca Guatemala. 2011.

11. Consejo Indígena de Centroamérica. Los 
pueblos indígenas en el marco de la integración centroamericana. 2007. URL: http://www. observatorioca-ue.com/html/posiciones/anexos/ CICA-ADA1.pdf

12. FLACSO-Costa Rica. Memoria Fondo Participación de los Sectores Sociales en Vulnerabilidad y Exclusión en el Proceso de Integración Regional Centroamericana "PASIRCA": Una experiencia de inclusión de la sociedad civil en el proceso de Integración Centroamericana. 2014. URL: https://eeas.europa.eu/delegations/ nicaragua/documents / press_corner/ publications/20150407_02_es.pdf

13. Fonseca, E. Centroamérica: su historia. San José, Costa Rica: FLACSO. 1996.

14. García Gónzález, D. \& Chacón González, Vivian Noelia. ¿...YY para cuándo los bienes públicos? Democracia, desarrolloy territorio en Centroamérica y República Dominicana. Guatemala: AECIDFundación DEMUCA. 2018.

15. Giménez, G. La cultura como identidad y la identidad como cultura. 2005. URL: http://perio. unlp.edu.ar/teorias2/textos/articulos/gimenez.pdf

16. Gudynas, E., \& Acosta, A. La renovación de la crítica al desarrollo y el buen vivir como alternativa. Utopía y Praxis Latinoamericana. 2011; 16(53): 71-83. URL: http://www.redalyc.org/ articulo.oa? $\mathrm{id}=27919220007$

17. Harris, M. Antropología cultural. España: Editorial Alianza. 2001.

18. Kim-Kimen A.N., Kuznetsova Z.M. The development of the traditions of ancestors to the glory of the Yakut Sports. Pedagogiko-psikhologicheskie I medico-biologicheskie problem fizicheskoi kultury I sporta $=$ The Russian Journal of Physical Education and Sport. 2018; 13(2): 119-123 (In Russ., In Engl.).

19. Lavega, P., Lagardera, F., Molina, F., Planas, A., Costes, A., \& de Ocariz, U. S. Los juegos y deportes tradicionales en Europa: entre la tradición y la modernidad. Apunts. Educación física y deportes. 2006; 3(85): 68-81.

20. Lavega, P., Alonso, J.I., Etxebeste, J., Lagardera, F., \& March, J. Relationship between traditional games and intensity of emotions experienced by participants. Research Quarterly for Exercise and Sport. 2014; 85: 457-467. doi: 10.1080/02701367.2014.961048

21. Lavega, P., Etxebeste, J. Sáez de Ocáriz, U. Serna, J. \& During, B. Apprendre à vivre ensemble par les jeux sportifs traditionnels. In G. Ferréol (ed.) Égalité, mixité, intégration par le sport. 2016: 129146.

22. Lora, P. Derechos humanos y diálogo intercultural: repensando las relaciones asimétricas entre culturas. Polisemia. 2015; (19): 15-24. URL: http://biblioteca.uniminuto.edu/ojs/index.php/ POLI/article/view/1176/1081

23. Martínez, M., \& Larrea, C. Antropología social, desarrollo y cooperación internacional:
Introducción a los fundamentos básicos y debates actuales. Barcelona, España: Editorial UOC. 2010.

24. Milton, K. Emotion Life, the Universe, Everything. The Australian Journal Of Anthropology. $2005 ; 16(2)$.

25. Md Al Mamun, Kuznetsova Z.M. History of Drop Roball. Pedagogiko-psikhologicheskie I medico-biologicheskie problem fizicheskoi kultury I sporta $=$ The Russian Journal of Physical Education and Sport. 2018; 13(2): 98-106 (In Russ., In Engl.).

26. Naciones Unidas, Consejo Económico y Social. Comité de Derechos Económicos, Sociales y Culturales. Observación general. 2010; 21.

27. Naciones Unidas., PNUD., \& UNESCO. Creative Economy Report 2013 Special Edition: Widening local development pathways. 2013. URL: http://www.unesco.org/culture/pdf/creativeeconomy-report-2013.pdf

28. Organización de Estados Iberoamericanos (OEI)., \& Secretaría General Iberoamericana (SEGIB). Carta Cultural Iberoamericana. XVI Cumbre Iberoamericana de Jefes de Estado y de Gobierno, Uruguay, 4 y 5 de noviembre de 2006. 2006. URL: http://www.oei.es/xvi/xvi_culturaccl. pdf

29. Parlebas, P. Juegos, deporte y sociedad. Léxico de Praxiología motriz. Barcelona: Paidotribo (1 ${ }^{\text {a }}$ Edición 1981). 2001.

30. Pérez, H. La diversidad cultural y las lógicas del mestizaje en América Central. Manuscrito inédito. 2012. URL: http://www.academiaghcr. com/pdf/La_diversidad_cultural.pdf

31. Recinos, A. Popol Vuh: Las antiguas historias del Quiché. México: Berbera. 2006.

32. Rodríguez, J. M. Métodos de investigación cualitativa. Revista de Silogismos de Investigación. 2011; 1(08). URL: http://www.cide.edu.co/ojs/ index.php/silogismo/article/view/64/53

33. Romero, R. R. ¿Cultura y desarrollo? ¿Desarrollo y cultura?: Propuestas para un debate abierto. Serie Desarrollo Humano. 2005; 9. URL: http://unesdoc.unesco.org/ images/0014/001440/144076s.pdf

34. Ruiz, J., \& Ispizua, M. A. La descodificación de la vida cotidiana: Métodos de investigación cualitativa. Bilbao: Universidad de Deusto. 1989.

35. Sánchez Paredes, J. E. Tradición oral como herramienta de preservación cultural del pueblo Salasaka (Bachelor's thesis, Universidad Técnica de Ambato, Facultad de Jurisprudencia y Ciencias Sociales, Carrera de Comunicación Social). 2018.

36. Scribano, A. O. El proceso de investigación social cualitativo. Buenos Aires, Argentina: Prometeo Libros Editorial. 2008.

37. SICA. Política Cultural de Integración Centroamericana 2012-2030. 2017. URL: http:// www.ceccsica.info/sites/default/files/docs/ Politica-cultural_esp.pdf
38. UNESCO. 
Salvaguarda del Patrimonio Cultural Inmaterial. 2003. URL: http://unesdoc.unesco.org/ images/o013/001325/132540s.pdf

39. UNESCO. Convención sobre la Protección y la Promoción de la Diversidad de las Expresiones Culturales. 2005. URL: http://www.iedf.org.mx/ sites/DDHH/convenciones/17.pdf

40. UNESCO. Una nueva agenda de políticas culturales para el desarrollo y la comprensión mutua. División de Políticas Culturales y Diálogo Intercultural. 2010. URL: http://unesdoc.unesco. org/images/o021/o02147/214747s.pdf

41. UNESCO. Culture: key to sustainable development. Hangzhou International Congress I China. 2013. URL: http://www.unesco.org/new/ en/culture/themes/culture-and-development/ hangzhou-congress/

\section{Submitted: 10.07.2019}

Author's information:

Luis Bruzón Delgado - Culture and Communication Coordinator, Central American Educational and Cultural Coordination, Central American Integration System (CECC/SICA), San José, Costa Rica (Central America), e-mail: sulayum@gmail.com 